Tropical Journal of Pharmaceutical Research June 2017; 16 (6): 1399-1406

ISSN: $1596-5996$ (print); 1596-9827 (electronic)

(C) Pharmacotherapy Group, Faculty of Pharmacy, University of Benin, Benin City, 300001 Nigeria.

All rights reserved.

Available online at http://www.tjpr.org

Original Research Article

http://dx.doi.org/10.4314/tjpr.v16i6.26

\title{
Effect of different drying techniques on the volatile compounds, morphological characteristics and thermal stability of Stevia rebaudiana Bertoni leaf
}

\author{
Mohammed Abdalbasit A Gasmalla ${ }^{1,2}$, Habtamu A Tessema ${ }^{3}$, Kamal Alahmed ${ }^{3}$, \\ Xiao Hua ${ }^{3}$, Xiangru Liao ${ }^{4}$ and RuijinYang ${ }^{1,3 \star}$ \\ ${ }^{1}$ State Key Laboratory of Food Science \& Technology, Jiangnan University, 1800 Lihu Avenue, Wuxi 214122, Jiangsu, China, \\ ${ }^{2}$ Department of Nutrition \& Food technology, Faculty of Science and Technology, Omdurman Islamic University, PO Box 382, \\ 14415, Khartoum, Sudan, ${ }^{3}$ School of Food Science and Technology, Jiangnan University, 1800 Lihu Avenue, ${ }^{4}$ The Key \\ Laboratory of Industrial Biotechnology, Ministry of Education, School of Biotechnology, Jiangnan University, 1800 Lihu Road, \\ Wuxi 214122, Jiangsu, China
}

*For correspondence: Email: yrj@jiangnan.edu.cn; Tel: + 86-510-85919150; Fax: +86510-85919150

\begin{abstract}
Purpose: To examine the volatile compounds, thermal stability and morphological characteristics of stevia (Stevia rebaudiana Bertoni) leaves after sun, oven and microwave drying.

Methods: Gas chromatography-mass spectrometry with a spectral analysis manager was used to separate the volatile compounds. Dried stevia leaf powder was characterized morphologically by scanning electron microscopy while thermal properties were determined by differential scanning calorimetry (DSC).

Results: The plant material contained large amounts of spathulenol and caryophyllene oxide. The main compounds were 1-docosanol and hexanoic acid; trans- $\beta$-ionone, 5-methylundecane, 2,5,6trimethyldecane, (+) spathulenol, propanoic acid and 1-chlorononadecane. The surface of the dried leaf powder varied with the treatment applied. Following microwave drying, the particles were even, regular, and compact while the sun- and oven dried particles resembled angular bricks. All samples exhibited a strong endothermic response, indicating stability up to $150{ }^{\circ} \mathrm{C}$; from 150 to $200{ }^{\circ} \mathrm{C}$, thermal decomposition occurred.

Conclusion: Drying method has a significant effect on the structure, thermal stability and volatile compounds contents of stevia leaves. All drying methods examined in this study have potential applications in the preparation of stevia as a functional ingredient for the food and pharmaceutical industries.
\end{abstract}

Keywords: Differential scanning calorimetry, Drying techniques, Stevia rebaudiana, Pharmaceuticals, Scanning electron microscopy, Volatile compounds

Tropical Journal of Pharmaceutical Research is indexed by Science Citation Index (SciSearch), Scopus, International Pharmaceutical Abstract, Chemical Abstracts, Embase, Index Copernicus, EBSCO, African Index Medicus, JournalSeek, Journal Citation Reports/Science Edition, Directory of Open Access Journals (DOAJ), African Journal Online, Bioline International, Open-J-Gate and Pharmacy Abstracts

\section{INTRODUCTION}

Stevia (Stevia rebaudiana Bertoni), a bushy shrub of the Asteraceae family that originates from South America [1], is cultivated worldwide [2]. Stevia is known for its high content of sweet components. Studies of dry extracts have shown that stevia leaves contain flavonoids, alkaloids, chlorophylls, xanthophylls, hydroxycynnamic acids (e.g., caffeic acid and chlorogenic acid), oligosaccharides, free sugars, amino acids, lipids, and trace elements $[3,4]$. 
Table 1: Structure and comparison of the sweet glycosides present in Stevia rebaudiana

\begin{tabular}{|c|c|c|}
\hline Compound & $\mathbf{R}_{1}$ & $\mathbf{R}_{\mathbf{2}}$ \\
\hline Steviol & $\mathrm{H}$ & $\mathrm{H}$ \\
\hline Stevioside & $\beta-G \mid c$ & $\beta$-Glc- $\beta$-Glc $(2 \rightarrow 1)$ \\
\hline Steviolbioside & $\mathrm{H}$ & $\beta$ - Glc- $\beta$-Glc $(2 \rightarrow 1)$ \\
\hline Rebaudioside A & $\beta-$ Glc & $\begin{array}{l}\beta-\text { Glc- } \beta-\text {-Glc }(2 \rightarrow 1) \\
\beta-\text { Glc- }(3 \rightarrow 1)\end{array}$ \\
\hline Rebaudioside B & $\mathrm{H}$ & $\begin{array}{l}\beta-\text { Glc- } \beta-G l c(2 \rightarrow 1) \\
\beta-\text { Glc- }(3 \rightarrow 1)\end{array}$ \\
\hline $\begin{array}{l}\text { Rebaudioside C } \\
\text { (Dulcoside B) }\end{array}$ & $\beta-$ Glc & $\begin{array}{l}\beta \text { - Glc- } \alpha-R h a(2 \rightarrow 1) \\
\beta \text { - Glc- }(3 \rightarrow 1)\end{array}$ \\
\hline Rebaudioside D & $\beta$ - Glc- $\beta$-Glc $(2 \rightarrow 1)$ & $\begin{array}{l}\beta \text { - Glc- } \beta \text {-Glc }(2 \rightarrow 1) \\
\beta \text { - Glc- }(3 \rightarrow 1)\end{array}$ \\
\hline Rebaudioside E & $\beta$ - Glc- $\beta$-Glc $(2 \rightarrow 1)$ & $\beta$ - Glc- $\beta$-Glc $(2 \rightarrow 1)$ \\
\hline Rebaudioside F & $\beta$ - Glc & $\begin{array}{l}\beta-\text { Glc- Xyl }(2 \rightarrow 1) \\
\beta-\text { Glc- }(3 \rightarrow 1)\end{array}$ \\
\hline Dulcoside A & $\beta$ - Glc & $\beta$ - Glc- $\alpha-R h a(2 \rightarrow 1)$ \\
\hline
\end{tabular}

The major constituents of stevia leaves are the potently sweet diterpenoid glycosides, stevioside, rebaudiosides $A$ and $D$, and dulcoside $A$ (Figure 1). These compounds are glycosides of the diterpene steviol (ent-13-hydroxykaur-16-en-19oic acid); their chemical structures are provided in Table 1 [5]. Different methods, including airdrying in the shade, sun drying, and oven drying, are used to dehydrate the plants. Capecka et al [6] demonstrated the efficacy of shade drying (the simplest and cheapest method) for the leaves of Lamiaceae species. Chan et al [7] used hot air to accelerate the leaf-drying process in ginger species, and Pinela et al. [8] employed the same method for Fabaceae species. A newer technique, freeze-drying, has been shown to better preserve the quality of medicinal plants although it is considerably more costly than hot air drying [9].<smiles>C=C1C[C@@]23CCC4[C@@](C)(C(=O)O)CCC[C@]4(C)C2CC[C@@]1(O)C3</smiles>

Figure 1: Chemical structure of major sweet glycosides. R1, R2: The constituents attached to the base structure of steviol are glucose, rhamnose, and xylose sugar moieties

Different drying techniques can influence the composition of some characteristic compounds present in herbal teas. Improved antioxidant capacity and total phenol values were obtained when Echinacea purpurealeaves were freeze- dried than when they were dehydrated with hot air [10]. Pinela et al [8] also retained higher antioxidant levels when Genista sp. leaves were freeze-dried than when they were shade-dried. Conversely, less antioxidant was retained by freeze-drying leaves of the Lamiaceae family than by hot air drying [11].

This study is the first investigation of the effects of drying techniques on stevia leaves grown in China. This study provides new information about these effects and may open new avenues for research on stevia leaves. The objectives of the study were to determine the chemical volatile compounds, morphological characteristics, and thermal stability of stevia leaves. It is hoped that the results will have practical applications in the development of novel foods.

\section{EXPERIMENTAL}

\section{Materials}

Stevia leaves were obtained from Yancheng Xiaguang Stevioside Trading Company Ltd. (Jiangsu, China) soon after harvesting, and then transported to the laboratory and preserved until use. Dr. Tan Ya Li of the School of Medicine and Pharmaceutics, Jiangnan University (Wuxi, China) authenticated the plant material, and a specimen (voucher no. 3-YXSTC-29/09/11) was deposited in the herbarium of the School of Food Science and Technology (Jiangnan University, Wuxi, China) [12].

The leaves were ground to a powder using a high-speed blender (at 25,000 rpm) (WK-1000A; Qing Zhou Jing Cheng Machinery, Shandong, 
China). The powder was filtered through a 100mesh sieve, packed in polyethylene bags, and stored at $4{ }^{\circ} \mathrm{C}$ until use. All chemicals and reagents used in this study were of analytical grade.

\section{Analysis of volatile compounds}

Gas chromatography-mass spectrometry (GCMS) was performed using a spectral analysis manager to separate volatile compounds with a CP-Sil-8CB (Varian, Walnut Creek, CA, USA) fused silica capillary column (length: $30 \mathrm{~m}$; inner diameter: $0.25 \mathrm{~mm}$; film thickness: $0.25 \mu \mathrm{m}$ ) in a Varian model 3800 gas chromatograph. Helium was used as the carrier gas, with a constant flow of $0.9 \mathrm{ml} / \mathrm{min}$. The splitless mode injector was maintained at $220{ }^{\circ} \mathrm{C}$, and the flame ionization detector at $250{ }^{\circ} \mathrm{C}$. Volatile compounds were separated using a DB-WAX capillary column (30 $\mathrm{m} \times 0.25 \mu \mathrm{m} ; \mathrm{J}$ and $\mathrm{W}$ Scientific, Folsom, CA, USA). Separation was performed as follows: the oven temperature was set to $40{ }^{\circ} \mathrm{C}$ for $3 \mathrm{~min}$, increased to $100{ }^{\circ} \mathrm{C}$ at a rate of $6{ }^{\circ} \mathrm{C} / \mathrm{min}$, and then raised to $230^{\circ} \mathrm{C}$ at $10^{\circ} \mathrm{C} / \mathrm{min}$. Mass spectra were obtained in electron impact mode at $70 \mathrm{eV}$; the mass range was $33-450 \mathrm{~m} / \mathrm{z}$. Volatile compounds in the dried stevia leaves were identified by matching their mass spectra to standard compounds listed in the following MS libraries: Wiley 130K (http://www.palisade.com), National Institute of Standards and Technology 98 (http://www.nist.gov). Some identifications were confirmed by the injection of chemical standards into the GC-MS system.

\section{Scanning electron microscopy (SEM)}

We observed the stevia leaf powders by SEM (Hitachi SU1510; Hitachi, Tokyo, Japan) for morphological characterization. Three powder samples (sun-, oven-, and microwave-dried) were analyzed. Dried sample particles were fixed on a $8 \mathrm{~mm} \times 20 \mathrm{~m}$ specific carbon-film support (HIS2854 No.7321; Nisshin EM, Tokyo, Japan), and their shape and surface characteristics were observed using a gaseous secondary electron detector in environmental mode.

\section{Differential scanning calorimetry (DSC)}

The thermal properties of the stevia leaves were analyzed by DSC (Q200 V24.8, build 120; TA Instruments, New Castle, DE, USA). Approximately $8.5-9.5 \mathrm{mg}$ of dried stevia leaves were weighed in aluminum pans that were then hermetically sealed and heated from -20 to 200 ${ }^{\circ} \mathrm{C}$ at a rate of $10{ }^{\circ} \mathrm{C} / \mathrm{min}$. An empty sample container was used as the reference pan.

\section{Statistical analysis}

All experiments were conducted in triplicate. An analysis of variance was performed, and significant differences (at $p<0.05$ ) between mean values were evaluated by Fisher's least significant difference test using SPSS version 19.0 (SPSS Inc., Chicago, IL, USA).

\section{RESULTS}

\section{Volatile contents}

The chromatographic profile of the dried stevia leaves contained a wide variety of volatiles. The main compounds were 1-docosanol, hexanoic acid, and trans- $\beta$-ionone. Other compounds such as 5-methylundecane, 2,5,6-trimethyldecane, $(+)$ spathulenol, propanoic acid, and 1-chlorononadecane occurred at low concentrations (Table 2).

Table 2: Volatile composition of Stevia rebaudiana Bertoni

\begin{tabular}{|c|c|c|c|c|}
\hline \multirow[b]{2}{*}{ Compound } & \multirow[b]{2}{*}{$\begin{array}{l}\text { Chemical } \\
\text { classification }\end{array}$} & \multicolumn{3}{|c|}{ Relative peak area (\%) } \\
\hline & & $\begin{array}{l}\text { Sun (Ambient } \\
\text { temperature } \\
\text { for } 5 \text { days) }\end{array}$ & $\begin{array}{l}\text { Oven } \\
\left(60^{\circ} \mathrm{C} \text { for }\right. \\
16 \mathrm{~h})\end{array}$ & $\begin{array}{l}\text { Microwave } \\
\text { (2450MHz, } \\
700 W \text { for } 6 \mathrm{~min})\end{array}$ \\
\hline Acetic acid & Acids & $2.18 \quad 2$ & 2.92 & 3.91 \\
\hline Propanoic acid & Acids & 2.17 & ND & ND \\
\hline 1-Azabicyclo[3.2.1]octan-6-ol & Alcohols & 5.77 & ND & ND \\
\hline Hexanal & Aldhaydes & 2.47 & 8.66 & ND \\
\hline 2,4-Pentadienal & Aldhaydes & 1.16 & 7.59 & 4.2 \\
\hline Pyrimidine, 4-methyl- & Amines & 3.49 & 2.51 & ND \\
\hline 3-Methyl pentanoic acid & Esters & 1.95 & ND & 2.2 \\
\hline Pentanoic acid & Acids & 4.45 & 2.51 & 3.96 \\
\hline $2(3 \mathrm{H})$-Furanone, dihydro- & Ketones & 2.61 & 3.25 & ND \\
\hline 4-Pentenal, 2-ethyl- & Esters & 6.23 & ND & ND \\
\hline Hexanoic acid & Acid & 7.28 & 2.31 & 9.92 \\
\hline Octanal & aldhaydes & 2.55 & 1.21 & 2.35 \\
\hline Trans 2-hexenoic acid & Acids & 2.54 & 1.72 & 9.9 \\
\hline
\end{tabular}


Table 2: Volatile composition of Stevia rebaudiana Bertoni (continued)

\begin{tabular}{|c|c|c|c|c|}
\hline \multirow[b]{2}{*}{ Compound } & \multirow[b]{2}{*}{$\begin{array}{l}\text { Chemical } \\
\text { classification }\end{array}$} & \multicolumn{3}{|c|}{ Relative peak area (\%) } \\
\hline & & $\begin{array}{l}\text { Sun (Ambient } \\
\text { temperature } \\
\text { for } 5 \text { days) }\end{array}$ & $\begin{array}{l}\text { Oven } \\
\left(60^{\circ} \mathrm{C} \text { for }\right. \\
16 \mathrm{~h})\end{array}$ & $\begin{array}{l}\text { Microwave } \\
\text { (2450MHz, } \\
\text { 700W for } 6 \mathrm{~min} \text { ) }\end{array}$ \\
\hline Cyclohexane, nitro- & Alkanes & 3.4 & ND & 4.73 \\
\hline $2(3 \mathrm{H})$-Furanone, 5-ethenyldihydro-5-methy & Ketones & 1.73 & ND & ND \\
\hline $2(3 \mathrm{H})$-Furanone, 5-ethyldihydro- & Ketones & 1.87 & 1.59 & 2.47 \\
\hline Heptanoic acid & Acids & 6.59 & 1.78 & 1.99 \\
\hline Heptadecane, 2,6-dimethyl- & Alkanes & 3.33 & ND & 1.77 \\
\hline Decane, 2,6,7-trimethyl- & Alkanes & 4.43 & ND & 7.28 \\
\hline Hydroxylamine, O-decyl- & Amines & 3.98 & 1.65 & ND \\
\hline Nonanal & aldhaydes & 1.46 & 6.73 & 2.59 \\
\hline Decane, 2,6,7-trimethyl- & Alkanes & 7.05 & ND & ND \\
\hline Tetradecane & Alkanes & 4.53 & 7.72 & 1.36 \\
\hline Dodecane, 2,6,10-trimethyl- & Alkanes & 5.57 & ND & 7.28 \\
\hline 2,3-Dimethyldecane & Alkanes & 2.79 & ND & ND \\
\hline 2-Ethyl-1-dodecanol & Alcohols & 1.45 & 6.19 & ND \\
\hline Undecane & Alkanes & ND & 1.32 & 3.98 \\
\hline Octanoic acid & Acids & 1.83 & ND & ND \\
\hline Undecane, 5-methyl- & Alkanes & ND & 2.4 & 6.90 \\
\hline Docosane & Alkanes & 1.46 & ND & ND \\
\hline Bicyclo[4.4.1]undeca-1,3,5,7,9-pentaen-1 & Hydrocarbons & 1.61 & ND & 1.36 \\
\hline 3-Cyclohexene-1-methanol, .alpha.,.alpha & Alkenes & 8.07 & ND & ND \\
\hline Dodecane & Alkanes & 1.7 & ND & 8.04 \\
\hline Decanal & aldehydes & 1.31 & 4.77 & 2.54 \\
\hline Heptadecane & Alkanes & 8.47 & 6.48 & 1.53 \\
\hline 1-Cyclohexene-1-carboxaldehyde, 2,6,6-tr & Aldehyde & 1.27 & ND & ND \\
\hline 2,5-dimethyl-5-nitrohexanal & Aldehydes & 1.61 & ND & ND \\
\hline 2-Hexenal, (E)- & Aldehydes & ND & 3.31 & ND \\
\hline Ethylbenzene & Aromatic & ND & ND & 1.45 \\
\hline Benzene, pentamethyl- & Aromatic & 1.22 & ND & ND \\
\hline Naphthalene, 2-methyl- & Aromatic & 1.17 & ND & ND \\
\hline Nonadecane & Alkanes & ND & 4.83 & 2.11 \\
\hline 2-Heptenal, (Z)- & Aldehydes & ND & 1.95 & ND \\
\hline Cyclopentadecanone, 4-methyl- & Ketones & 7.38 & ND & ND \\
\hline 3,3-dimethyl-2,7-octanedione & Ketones & ND & 8.6 & 2.07 \\
\hline Triacetin & Esters & 6.62 & ND & ND \\
\hline 1-Docosanol & Alcohols & 9.99 & ND & ND \\
\hline (+)-Aromadendrene & Aromatic & 9.16 & ND & ND \\
\hline 5,9-Undecadien-2-one, 6,10-dimethyl- & Ketones & 1.57 & ND & 1.98 \\
\hline Heptafluorobutyric acid, n-pentadecyl es & Esters & 9.25 & ND & 1.7 \\
\hline 3-Isopropoxy-1,1,1,7,7,7-hexamethyl-3,5, & Hydrocarbons & 2.93 & ND & ND \\
\hline $2 \mathrm{H}-1$-Benzopyran, 3,5,6,8a-tetrahydro-2,5 & Ketones & 2.63 & ND & ND \\
\hline (+) spathulenol & Alcohols & 6.04 & 1.04 & 6.55 \\
\hline Nonadecane, 1-chloro- & Aliphatic & 1.05 & ND & ND \\
\hline $2(4 \mathrm{H})$-Benzofuranone, $5,6,7,7$ a-tetrahydro & Ketones & 5.55 & 2.57 & 9.64 \\
\hline (-)-Caryophyllene oxide & Alkenes & 2.03 & 1.21 & 4.05 \\
\hline Pseudosolasodine diacetate & Esters & 9.98 & ND & ND \\
\hline 1-Bromo-2-methyl-decane & Alkanes & 1.71 & ND & 2.09 \\
\hline Octadecane, 1-chloro- & Aliphatic & 1.28 & 2.03 & ND \\
\hline 1-Naphthalenol, $1,2,3,4,4 a, 7,8,8 a-o c t a h y$ & Alcohols & 2.94 & ND & ND \\
\hline Caryophyllene oxide & Alkenes & 3.06 & 1.41 & 2.57 \\
\hline Tetradecane, 2,6,10-trimethyl- & Alkanes & 9.36 & ND & ND \\
\hline 2-Pentadecanone, 6,10,14-trimethyl- & Ketones & 8.95 & 3.55 & 2.35 \\
\hline trans-.beta.-lonone & Ketones & ND & ND & 8.86 \\
\hline 1H-Pyrrole-2,5-dione, 3-ethyl-4-methyl- & Ketones & 2.35 & ND & 3.76 \\
\hline Phthalic acid, octyl tridec-2-yn-1-yl es & Esters & 3.41 & ND & ND \\
\hline Junipene & Alkenes & ND & 1.23 & 2.79 \\
\hline 9-Octadecenoic acid (Z)- & Acids & 1.28 & ND & ND \\
\hline 1-Naphthalenecarboxylic acid, decahydro- & Acids & 5.48 & ND & ND \\
\hline Decane, 2,5,6-trimethyl- & Esters & ND & 4.2 & ND \\
\hline $9,12,15$-Octadecatrienoic acid, 2,3-dihyd & Acids & 3.42 & ND & ND \\
\hline 1H-Naphtho[2,1-b]pyran, 3-ethenyldodecah & Ketons & 1.72 & 7.6 & 6.84 \\
\hline
\end{tabular}

$N D=$ not detected 


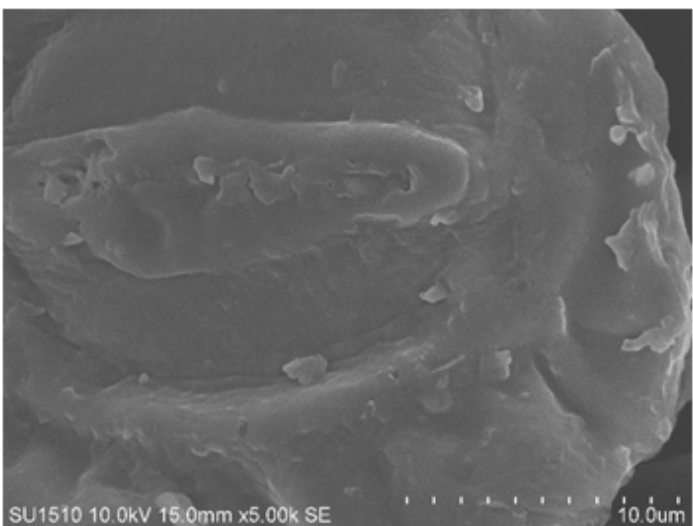

$\mathrm{A}$

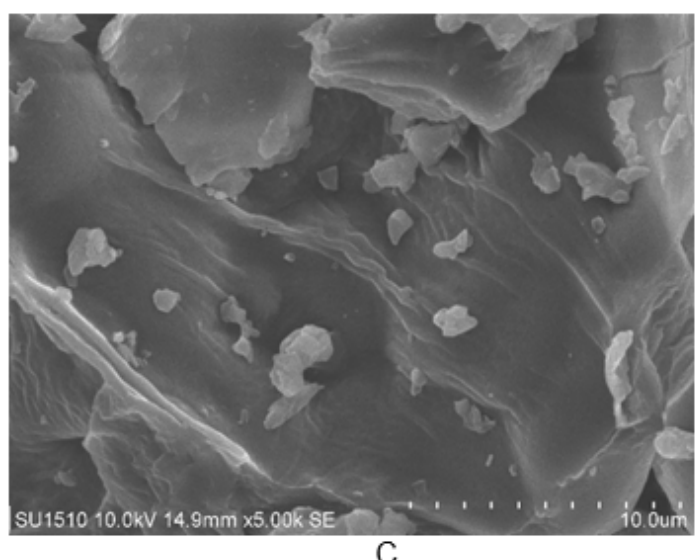

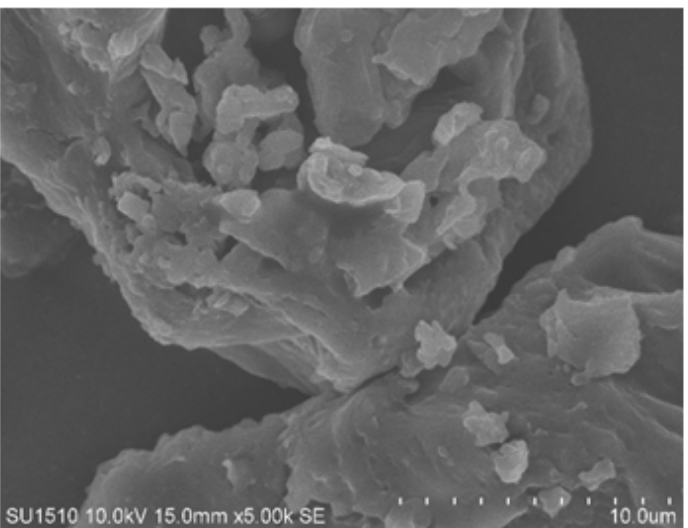

$\mathrm{B}$

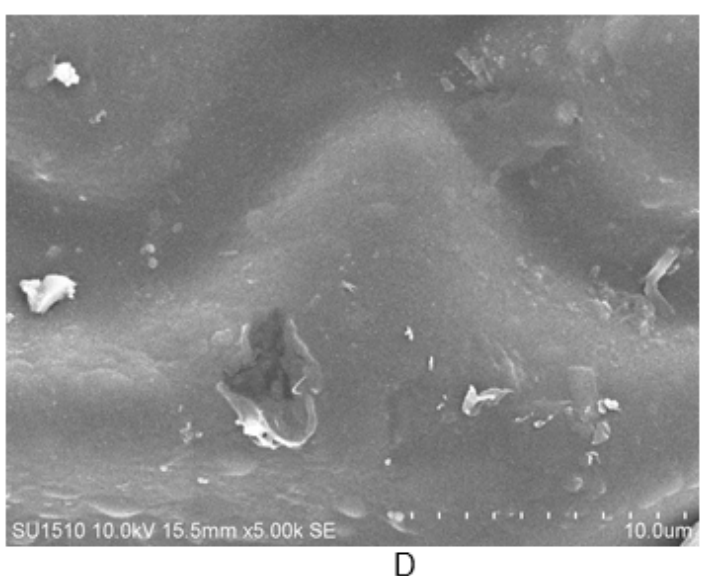

Figure 2: Scanning electron micrographs of the dried leaves of stevia: $(A)$ sun- drying (B) oven-drying (C) microwave -drying and (D) fresh leaves

A structural analysis of stevia leaves by SEM revealed that the surfaces of the three samples varied significantly in size and shape (Figure 2).

The thermal characteristics of the stevia leaf powder samples and related DSC properties are shown in Figure 3 . The samples were stable to $150{ }^{\circ} \mathrm{C}$; above this temperature, thermal decomposition occurred as the temperature increased to $200^{\circ} \mathrm{C}$, depending on position. The first sun-dried sample exhibited thermal decomposition, which occurred between 161 and $172{ }^{\circ} \mathrm{C}$, corresponding to a sharp endothermic peak at $164.11^{\circ} \mathrm{C}$, with a loss of water of constitution. The remaining two samples (ovenand microwave-dried) experienced thermal decomposition between $148-185^{\circ} \mathrm{C}$ and $182-$ $195^{\circ} \mathrm{C}$, overlapping with the temperature range for total mass loss. Two endothermic peaks, at 157.69 and $188.02^{\circ} \mathrm{C}$, were attributed to the oxidation of organic matter.

\section{DISCUSSION}

The chromatographic profile of the dried stevia leaves contained compounds within a wide variety of chemical classes. All samples contained abundant quantities of spathulenol and caryophyllene oxide. Studies of salvia sclerea oil, which is rich in spathulenol and caryophyllene oxide, have shown antibacterial activity against Staphylococcus aureus [13]. Markovic et al [14] showed that high numbers of sesquiterpenes and the presence of spathulenol and caryophyllene oxide could partially account for the antimicrobial activity of aqueous Stevia rebaudiana extracts.

Some compounds identified in stevia cultivated in Malaysia have been reported in plants from other locations, including Japan, Paraguay, and Serbia [14-16]. These include $\beta$-caryophyllene, germacrene D, nerolidol, spathulenol, caryophyllene oxide, and phytol. Stevia oils collected in several zones of Japan have been found to contain $\beta$-caryophyllene, caryophyllene oxide, nerolidol, (E)- $\beta$-farnesene, $\alpha$-humulene, and the monoterpenes linalool, terpinen-4-ol, and a-terpinol [15]. Martelli et al [17] analyzed dried leaves of a Brazilian stevia plant and found that the main constituents were caryophyllene oxide and spathulenol. Oven and microwave drying typically reveal considerable amounts of volatiles, as we found in the present study (Table 2). 

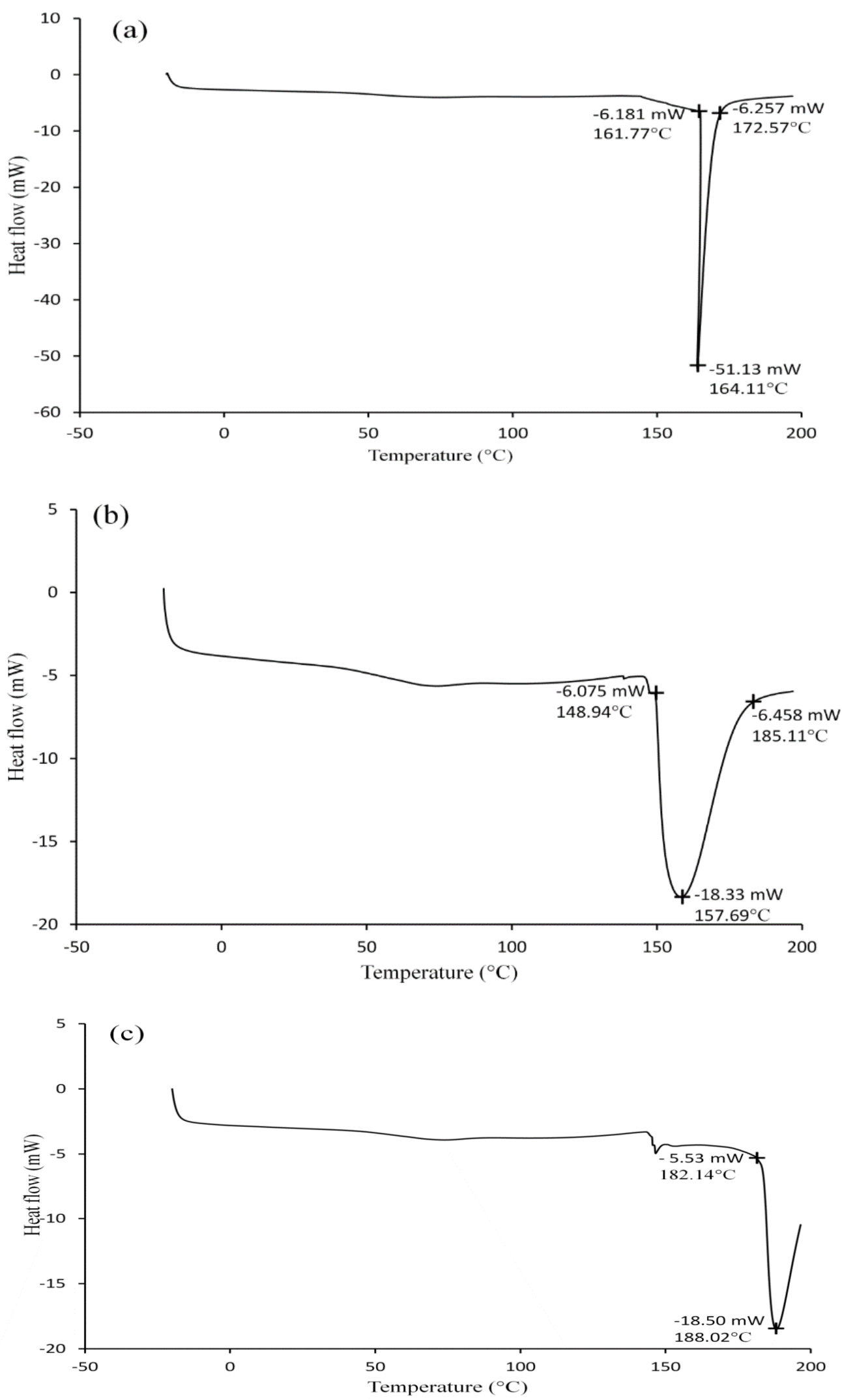

Figure 3: DSC curves for the stevia leaves: (a) sun-drying (b) oven-drying (c) microwave-drying

The quantity of volatiles found depends on the volatility and chemical structure of the constituents [18], with the exception of a small number of compounds such as cyclopropyl ursane-type triterpene acids. The probable reason for the increases we observed in some compounds during oven drying is the dehydration of oxygenated compounds; however, since the 
levels of oxygenated compounds were quite low in the sun-dried leaves, cell damage during the oven-drying process may also have been responsible.

The SEM of samples prepared using the three drying methods revealed significant variation in leaf surface size and shape. The microwavedried particles were evenly distributed, regular, and compact; the sun- and oven-dried samples resembled angular bricks. The oven-dried particles were comparatively rougher, more irregularly shaped, and porous; this explains the excellent rehydration properties of the oven-dried stevia samples. Differences in shape and size may be attributable to changes in interconnection and intermolecular distance caused by the different drying methods [7-11].

The micrographs in Figure 2 show structural features of the sun-, microwave-, and oven-dried samples. We observed complete parenchyma without significant cell wall damage; however, there were slight ruptures on the surfaces of the sun-dried samples that were not present in the microwave- and oven-dried samples. After microwave drying, the sample surface was significantly damaged, and the texture was crumbly due to the susceptibility of electromagnetic waves to sudden temperature increases during microwave irradiation; internal pressure increases due to high vapor pressure inside the cells can also accelerate cell rupture. Our results are consistent with those of Dahmoune et al [19]. Following oven drying (at $60{ }^{\circ} \mathrm{C}$ ), severe damage to cell walls was observed.

Microwave and oven drying likely initiated cell rupture and damage in the stevia leaves, which allowed more of the sweet compounds from the powder to be extracted by the solvent (water, ethanol, and isopropanol) [20]. Therefore, the total rebaudioside $\mathrm{A}$ and stevioside yields may be lower in leaves dried by the sun than in leaves dried using a microwave or oven. Further study is needed to assess the effect of sun drying on the yield of sweet compounds.

All three samples showed a strong endothermic response by DSC, indicating that the sweetening compounds in the leaves were largely unfolded and denatured. Exothermic peaks were not detected in any samples, although they may have been obscured by the broad desolvation event or the overlapping endothermic events that occurred during sample drying.

There was a difference in the thermal decomposition temperature $\left(T_{d}\right)$ between samples. The $T_{d}$ of microwave-dried stevia leaves was significantly higher than that of sunand oven-dried leaves (Figure 3), probably because of the potential of electromagnetic waves during microwave drying, which depends on irradiation. Conversely, the thermal decomposition was similar in leaves dried by the sun and oven, which depend on the application of direct heat.

The results of this study show that stevia is stable at high temperatures. Thus, products including stevia can be used at high temperatures without it breaking down like saccharin or aspartame. The decomposition that occurs during sun drying is caused by thermal decomposition of the compound with the loss of water of constitution. Thermal decomposition occurred during oven and microwave drying through the overlap of temperature zones with those for total mass loss, corresponding to the oxidation of organic matter. In contrast, the DSC thermograms displayed broad, relatively weak peaks. The absence of a strong endothermic melting peak at $157{ }^{\circ} \mathrm{C}$ in the DSC thermogram of the oven-dried samples suggests the presence of a stabilizing interaction, hindering the crystallization of amorphous steviol glycosides [21]. Only the microwave-dried sample displayed a non-negligible peak prior to decomposition near $150{ }^{\circ} \mathrm{C}$. This indicates that the stabilizing interaction dissipated somewhat during the homogenization process, resulting in the crystallization of small amounts of steviol glycosides, as evidence of a possible phase impurity.

\section{CONCLUSION}

The findings of this study show that the drying method has a significant effect on volatile compounds, thermal stability, and morphological characteristics of stevia leaves and can cause a serious decline in the content of standard phytochemical constituents. Microwave and oven drying are the most suitable methods to prepare stevia leaf for use in foods. Stevia leaf is a potential raw material for functional food ingredients as it is a rich source of nutrients, crude protein, carbohydrates, and dietary fiber. Further studies, however, are needed to evaluate their functionality in specific food products.

\section{DECLARATIONS}

\section{Acknowledgement}

The authors would like to acknowledge support from National Key Technology R\&D Program in the 12th Five year Plan of China (no. 
2011BAD23B03), Key Project of National Natural Science Fund (no. 31230057), and Open Research Project of Key Laboratory of Carbohydrate Chemistry and Biotechnology Ministry of Education (no. KLCCB-KF201206).

\section{Conflict of Interest}

No conflict of interest associated with this work.

\section{Contribution of Authors}

The authors declare that this work was done by the authors named in this article and all liabilities pertaining to claims relating to the content of this article will be borne by them.

\section{Open Access}

This is an Open Access article that uses a funding model which does not charge readers or their institutions for access and distributed under the terms of the Creative Commons Attribution License (http://creativecommons.org/licenses/by/ 4.0) and the Budapest Open Access Initiative (http://www.budapestopenaccessinitiative.org/rea d), which permit unrestricted use, distribution, and reproduction in any medium, provided the original work is properly credited.

\section{REFERENCES}

1. Soejarto D. Botany of Stevia and Stevia rebaudiana. In: Kinghorn A (Ed), Stevia: The genus Stevia. Taylor \& Francis, London, UK, 2002.

2. Rai C, Majumdar GC, De S. Primary Clarification of Stevia Extract: A Comparison between Centrifugation and Microfiltration. Separ Sci Technol 2013; 48: 113121.

3. Gisleine EC, Abdol HA, Caudio CA, Letícia de AFF, Gilson $T$, Mirian $H T$, Wilson $E F$, Roberto $B B$. Investigation of the tolerability of oral Stevioside in Brazilian hyperlipidemic Patients. Braz Arch Biol Technol 2006; 49: 583-587.

4. Jianwei $Z$, Wenguo $C$, Wenting $Y$, Wei W. Antioxidant Abilities, Phenolics and Flavonoids Contents in the Ethanolic Extracts of the Stems and Leaves of Different Stevia rebaudiana Bert Lines. Sugar Tech 2013; 15 : 209-213.

5. Geuns JMC. Stevioside. Phytochemistry 2003; 64: 913921.

6. Capecka E, Mareczek A, Leja M. Antioxidant activity of fresh and dry herbs of some Lamiaceae species. Food Chem 2005; 93: 223-226.

7. Chan EWC, Lim YY, Wong KK, Lim KK, Tan SP, Lianto FS, Yong MY. Effects of different drying methods on the antioxidant properties of leaves and tea of ginger species. Food Chem 2009; 113: 166-172.

8. Pinela J, Barros L, Carvalho AM, Ferreira I. Influence of the drying method in the antioxidant potential and chemical composition of four shrubby flowering plants from the tribe Genisteae (Fabaceae). Food Chem Toxicol 2011; 49: 2983-2989.

9. Abascal K, Ganora L, Yarnell E. The effect of freeze drying and its implications for botanical medicines: $A$ review. Phytother Res 2005; 19: 655-660.

10. Lin SD, Sung JM, Chen CL. Effect of drying and storage conditions on caffeic acid derivatives and total phenolics of Echinacea Purpurea grown in Tai. Food Chem 2011; 125: 226-231.

11. Hossain MB, Barry-Ryan C, Martin-Diana AB, Brunton $N P$. Effect of drying method on the antioxidant capacity of six Lamiaceae herbs. Food Chem 2010; 123: 85-91.

12. Gasmalla MAA, Yang R, Amadou I, Hua X. Nutritional Composition of Stevia rebaudiana Bertoni Leaf: Effect of Drying Method. Trop J Pharm Res 2014; 13: 61-65.

13. Ulubelen A,Topcu G, Eris C, Soenmez U, Kartal M, Kurucu S, Bozok-Johansson C. Terpenoids from Salvia sclarea. Phytochem 1994; 36: 971-974.

14. Markovic IS, Darmati ZA, Abramovic BF. Chemical composition of leaf extracts of Stevia rebaudiana grown experimentally in Vojvodina. J Serb Chem Soc 2008; 73: 283-297.

15. Fujita S, Taka K, Fujita Y. Miscellaneous contributions to the essential oils of the plants from various territories. $X L I$. The components of the essential oil of Stevia rebaudiana. J Pharm Soc Japan 1977; 97: 692-694.

16. Sholichin M, Yamasaki K, Miyama R, Yahara SS, Tanaka $O$. Labdane-type diterpenes from Stevia rebaudiana. Phytochem 1980; 19: 326-330.

17. Martelli A, Frattini $C$, Chialva F. Unusual essential oils with aromatic properties. 1. Volatile components of Stevia rebaudiana. Flav Fragr J 1985; 1:3-7.

18. Venskutonis PR. Effect of drying on the volatile constituents of thyme (Thymus vulgaris $L$ ) and sage (Salvia officinalis L). Food Chem 1997; 59: 219-227.

19. Dahmoune F, Boulekbache L, Moussi K, Aoun O, Spigno $G$, Madani K. Valorization of Citrus limon residues for the recovery of antioxidants: Evaluation and optimization of microwave and ultrasound application to solvent extraction. Ind Crops Prod 2013; 50: 77-87.

20. Gasmalla MAA, Yang R, Musa A, Hua X, Ye F. Influence of sonication process parameters to the state of liquid concentration of extracted rebaudioside A from Stevia (Stevia rebaudiana Bertoni) leaves. Arab J Chem 2014;doi:10.1016/j.arabjc.

21. Mani U, Ken S, You LC, ShaoXW, Indra P. Solubility Enhancement of Steviol Glycosides and Characterization of Their Inclusion Complexes with Gamma-Cyclodextrin. Int J Mol Sci.2011; 12: 75297553. 